\title{
Identification of hematein as a novel inhibitor of protein kinase CK2 from a natural product library
} Ming-Szu Hung1,2,3, Zhidong Xu1 ${ }^{1}$, Yu-Ching Lin'2,3, Jian-Hua Mao4, ChengTa Yang 2,5 , Pey-Jium Chang 3 , David M Jablons*1 and Liang You*1

\author{
Address: ${ }^{1}$ Thoracic Oncology Laboratory, Department of Surgery, Comprehensive Cancer Center, University of California, San Francisco, CA \\ 94115, USA, ${ }^{2}$ Division of Pulmonary and Critical Care Medicine, Chang Gung Memorial Hospital, Chiayi, Taiwan, R.O.C., ${ }^{3}$ Graduate Institute of \\ Clinical Medical Sciences, College of Medicine, Chang Gung University, Taoyuan, Taiwan, R.O.C., ${ }^{4}$ Life Sciences Division, Lawrence Berkeley \\ National Laboratory, University of California, Berkeley, CA, USA and ${ }^{5}$ Department of Respiratory Care, College of Medicine, Chang Gung \\ University, Taoyuan, Taiwan, R.O.C. \\ Email: Ming-Szu Hung - Ming-Szu.Hung@ucsfmedctr.org; Zhidong Xu - Zhidong.Xu@ucsfmedctr.org; Yu- \\ Ching Lin - lin0927@adm.cgmh.org.tw; Jian-Hua Mao -JHMao@lbl.gov; Cheng-Ta Yang - yang1946@cgmh.org.tw; Pey- \\ Jium Chang - peyjium@yahoo.com; David M Jablons* - David.Jablons@ucsfmedctr.org; Liang You* - Liang.You@ucsfmedctr.org \\ * Corresponding authors
}

Published: 6 May 2009

BMC Cancer 2009, 9:135 doi:10.1 186/147|-2407-9-135
Received: 17 July 2008

Accepted: 6 May 2009

This article is available from: http://www.biomedcentral.com//47/-2407/9//35

(C) 2009 Hung et al; licensee BioMed Central Ltd.

This is an Open Access article distributed under the terms of the Creative Commons Attribution License (http://creativecommons.org/licenses/by/2.0), which permits unrestricted use, distribution, and reproduction in any medium, provided the original work is properly cited.

\begin{abstract}
Background: Casein kinase 2 (CK2) is dysregulated in various human cancers and is a promising target for cancer therapy. To date, there is no small molecular CK2 inhibitor in clinical trial yet. With the aim to identify novel CK2 inhibitors, we screened a natural product library.

Methods: We adopted cell-based proliferation and CK2 kinase assays to screen CK2 inhibitors from a natural compound library. Dose-dependent response of CK2 inhibitors in vitro was determined by a radioisotope kinase assay. Western blot analysis was used to evaluate down stream Akt phosphorylation and apoptosis. Apoptosis was also evaluated by annexin-V/propidium iodide (PI) labeling method using flow cytometry. Inhibition effects of CK2 inhibitors on the growth of cancer and normal cells were evaluated by cell proliferation and viability assays.
\end{abstract}

Results: Hematein was identified as a novel CK2 inhibitor that is highly selective among a panel of kinases. It appears to be an ATP non-competitive and partially reversible CK2 inhibitor with an IC 50 value of $0.55 \mu \mathrm{M}$. In addition, hematein inhibited cancer cell growth partially through downregulation of Akt phosphorylation and induced apoptosis in these cells. Furthermore, hematein exerted stronger inhibition effects on the growth of cancer cells than in normal cells.

Conclusion: In this study, we showed that hematein is a novel selective and cell permeable small molecule CK2 inhibitor. Hematein showed stronger growth inhibition effects to cancer cells when compared to normal cells. This compound may represent a promising class of CK2 inhibitors.

\section{Background}

CK2 is a serine/threonine protein kinase composed of 2 catalytic subunits $\left(\alpha \alpha, \alpha^{\prime} \alpha^{\prime}\right.$ or $\left.\alpha \alpha^{\prime}\right)$ and 2 regulatory subunits $(\beta)$. CK2 is ubiquitously expressed and highly con- served in cells and plays multiple roles in cellular processes, including gene expression, protein synthesis, cell proliferation and apoptosis[1]. So far, CK2 is known to phosphorylate more than 300 proteins in cells and is 
also an important regulator of intracellular signalling pathways[2]. For example, CK2 promotes survival by increasing survivin expression via beta-catenin-Tcf/Lefmediated transcription[3]. CK2 also constitutively phosphorylates and upregulates Akt/PKB Ser129 in vitro and in vivo, which may be required for maximal activation of Akt/PKB[4].

Dysregulation of CK2 in association with other proteins also increases oncogenic potential of cells[5]. In transgenic mouse study, expression of CK2 $\alpha$ subunits in lymphocyte induces lymphoma, and the coexpression of cmyc protein results in neonatal leukemia[6]. Overexpression of $\mathrm{CK} 2 \alpha$ in the mammary gland of transgenic mouse induces mammary hyperplasia, dysplasia, and eventually adenocarcinomas[7]. In primary embryo fibroblasts, coexpression of CK $2 \alpha^{\prime}$ and H-Ras induces transformation[8]. Overexpression of CK2 has been noted in a variety of human cancers, including acute myeloid leukaemia[9], mammary gland[7], prostate[10], lung[11], head and neck[12], and kidney cancer[13], and also correlates with metastatic potential, undifferentiated histological type and poor clinical outcome in human cancers. As a result, CK2 is a potential candidate of targeted therapy for cancers[1]. Although CK2 inhibitors like TBB $(4,5,6,7$ tetrabrome benzotriazole) [14] and its derivatives $[1,15]$ have been shown to induce apoptosis in human cancer cells, more selective CK2 inhibitors are needed, since to our knowledge there is still not one CK2 small molecule inhibitor in clinical trials for cancer treatment yet.

In this study, we screened for potential CK2 inhibitors from a natural compound library via cell based proliferation and kinase assays. Through these assays, hematein was identified as a novel CK2 inhibitor. We further evaluated the dose dependent inhibition response of hematein on CK2 kinase activity in vitro and in cancer cells. Effects of hematein on apoptosis and cell growth were also evaluated in cancer and normal cells.

\section{Methods \\ Cell culture}

HeLa (CCL-2), HCT116 (CCL-247), A549 (CCL-185), A427 (HTB-53), WI-38 (CCL-75) and CCL-211 cell lines were purchased from American Type Culture Collection (Manassas, VA). Cells were grown in complete growth medium (Dulbecco's modified Eagle's medium for HeLa, A549 and CCL-211; Eagle's Minimum Essential Medium for WI-38; Roswell Park Memorial Institute's medium for HCT116 and A427) supplemented with $10 \%$ fetal bovine serum, 10 units $/ \mathrm{ml}$ penicillin and $10 \mu \mathrm{g} / \mathrm{ml}$ streptomycin at $37^{\circ} \mathrm{C}$ and $5 \% \mathrm{CO} 2$.

\section{Compound library}

A natural product library NPL 400 (Timtect Inc., Newark, DE) was used to screen possible CK2 inhibitors. This library is composed of 400 highly pure, rationally selected drug-like small-molecule compounds with molecular weights ranging from 183 to $832 \mathrm{Da}$. All compounds were $0.5 \mathrm{mg}$ powder form in individual wells of 96-well plates. After dissolved with $100 \mu \mathrm{L}$ of dimethyl sulfoxide (DMSO), compounds were stored at $-20^{\circ} \mathrm{C}$ with final concentrations of $5 \mathrm{mg} / \mathrm{ml}$. TBB was purchased from Sigma-Aldrich Co (St. Louis, MI).

\section{Cell proliferation and viability assay}

The CellTiter $96^{\circledR} \mathrm{AQ}_{\text {ueous }}$ One Solution Cell Proliferation Assay (MTS) (Promega, Madison, WI) was used to evaluate growth of normal and cancer cells after treatment by different compounds. Exponentially growing cells were plated in 96-well microtiter plates at $5 \times 10^{3}$ cells/well with indicated concentrations of compounds. After incubation with indicated amount of compounds for 48 hours, $20 \mu$ lof the CellTiter $96^{\circledast} \mathrm{AQ}_{\text {ueous }}$ One Solution Reagent was added directly to culture wells. Absorbance at $490 \mathrm{~nm}$ was recorded with a 96-well plate reader after 2 hours incubation.

CellTiter-Glo luminescent cell viability assay (Promega, Madison, WI) was used to evaluate the cytotoxicity of hematein. After incubation with indicated amount of compounds for 48 hours, $100 \mu$ l of the CellTiter-Glo reagent was added directly to culture wells. Following procedures recommended by the manufacture, the luminescence produced by the luciferase-catalyzed reaction of luciferin and ATP was measured using a laminator.

\section{Kinase assays}

The CK2 Kinase Assay/Inhibitor Screening Kit (CycLex Co. Ltd., Japan) was used for further screening of compounds for their CK2 inhibition effects in vitro according to manufacture's manual[16].

For determination of the dose dependent inhibition response of hematein, Casein Kinase 2 Assay Kit (Millipore, Bedford, MA) was used according to manufacture's protocol. Kinase assay was carried out in the presence of increasing amount of hematein in a final volume of $50 \mu \mathrm{l}$ containing $20 \mathrm{mM}$ MOPS (pH 7.2), $25 \mathrm{mM} \beta$-glycerol phosphate, $5 \mathrm{mM}$ EGTA, $1 \mathrm{mM}$ sodium orthovanadate, 1

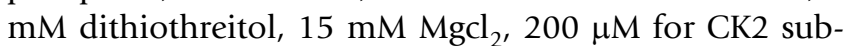
strate peptide: RRRDDDSDDD (Millipore, Bedford, MA), $0.05 \mu \mathrm{g}$ purified active CK2 (Millipore, Bedford, MA) and [ $\gamma$-33P]-ATP. After incubation in $30^{\circ} \mathrm{C}$ for 20 minutes, assay was stopped by adding of $20 \mu \mathrm{l} 4 \%$ trichloroacetic acid and transferred $25 \mu \mathrm{l}$ to P81 phosphocellulose squares. After washing with $0.75 \%$ phosphoric acid for 6 times and with acetone for 1 time, phosphocellulose 
squares were dried and transferred to scintillation vials for counting.

\section{Western blot analysis}

After treated with indicated concentration of hematein for 48 hours, whole cell protein were extracted from A549 cells with M-PER Mammalian Protein Extraction Reagent (Pierce, Rockfold, IL) added with Phosphatase Inhibitor Cocktail Set II (Calbiochem, San Diego, CA) and Complete Protease Inhibitor Cocktails (Roche, Switzerland) according to manufactures' protocols. The proteins were used for further CK2 kinase activity assay or western blot analysis. For western blot analysis, the proteins were separated on $4-15 \%$ gradient sodium dodecyl sulfate (SDS)polyacrylamide gels and transferred to Immobilon-P membranes (Millipore, Billerica, MA). Following primary antibodies: Akt, PARP (Cell Signaling Technology, Danvers, MA), phospho-Akt S129 (Abcam Inc., Cambridge, $\mathrm{MA}$ ) and $\beta$-actin (Sigma, St. Louis, MO) were used. After binding to indicated secondary antibodies, an enhanced chemiluminescence (ECL) blotting analysis system (GE Healthcare Life Sciences, Piscataway, NJ) was used for antigen-antibody detection.

\section{Apoptosis assay}

The occurrence of apoptosis was determined by ApoTarget $^{\mathrm{TM}}$ annexin V-FITC kit (BioSource International, Inc., Camarillo, CA). Briefly, cells were treated with indicated amounts of DMSO or hematein for 48 hours. The cells were washed with cold PBS and then re-suspended in binding buffer. The cells were aliquot to $100 \mu \mathrm{l}$ in a concentration of $1 \times 10^{6} / \mathrm{ml}$. After adding $5 \mu \mathrm{l}$ of annexin VFITC and $20 \mu \mathrm{l}$ of PI and incubated in dark for 15 minutes, the cells were resuspended in $400 \mu \mathrm{l}$ of binding buffer. Accuri's C6 Flow Cytometer ${ }^{\mathrm{rm}}$ System (Accuri Cytometers, Ann Arbor, MI) was used for analysis.

\section{Statistical analysis}

The data shown represent mean values \pm standard error of deviation (SD). Student's $t$-test was used for comparing of cell viability in different treatments. Statistical analysis was carried out using SPSS (version 10.0, Chicago, IL). Significance was defined as $\mathrm{p}<0.05$ with two sided analysis. The half maximal inhibitory concentration (IC50) values was determined using GraphPad Prism ${ }^{\circledast} \log$ (inhibitor) vs. response (variable slope) software (version 5, La Jolla, CA).

\section{Results}

Screening CK2 inhibitors from a natural compound library First, a cell based MTS cell proliferation assay was used to evaluate the inhibitory effects of 400 compounds from NPL compound library on cell proliferation of HCT116 cells. HCT116 cell was selected for initial screening because previous studies showed that this cell line was inhibited by CK2 inhibitors[17,18]. After incubation for 48 hours in 96-wells plates, a number of compounds including 4A3, 4A6 and 4A9, showed inhibition effects on HCT116 cells proliferation compared to control samples (DMSO) (Fig 1A).

Second, a non-isotopic CK2 kinase assay was performed to test the compounds selected from cell based inhibitory assay for their ability to inhibit CK2 kinase activity in vitro. Equal concentrations of the indicated compounds were incubated with purified CK2, and their inhibition effects were evaluated using $100 \mu \mathrm{M}$ ATP. Compared to $4 \mathrm{~A} 6$ and 4A9 compounds, 4A3 compound exerts stronger inhibition effect on CK2 kinase activity in vitro (Fig. 1B).

Third, the inhibition effects of selected compounds were further validated by radioisotope CK2 kinase assay at 10 $\mu \mathrm{M}$ ATP and similar results were noted (Fig. 2A). The 4A3 compound is hematein $(3,4,10$, 6a-tetrahydroxy-7, 6adihydroindeno $[2,1-\mathrm{C}]$ chroman-9-one) (Fig 2B).

Hematein inhibits CK2 kinase activity in a selective, dosedependent and ATP non-competitive manner in vitro

With the purpose to elucidate the specificity of hematein to CK2, a kinase panel provided by KinaseProfiler ${ }^{\mathrm{TM}}$ service (Millipore, Dundee, UK) was performed. Among 48 kinases tested in the presence of $10 \mu \mathrm{M}$ ATP and $10 \mu \mathrm{M}$ hematein, hematein exerts $>90 \%$ inhibition toward CK2 (Table 1). The $\mathrm{IC}_{50}$ value of hematein is $0.55 \mu \mathrm{M}$ in the presence of $10 \mu \mathrm{M}$ ATP (Fig 3A). However, the $\mathrm{IC}_{50}$ value did not increase in correspondence to $100 \mu \mathrm{M}$ ATP $(0.27$ $\mu \mathrm{M})$ (Fig 3A). Kinetics study was further performed and the Linewear-Burk plots showed that hematein is an ATP non-competitive inhibitor (Fig 3B).

\section{Hematein inhibits CK2 kinase activity in a partially reversible manner in vitro}

Reversibility test was performed with pre-incubation of hematein with CK2 in a concentration of $5 \mu \mathrm{M}$ for 30 minutes. CK2 kinase assay was then performed with the final concentration of $0.2 \mu \mathrm{M}$ hematein. The group with pre-incubation showed roughly $50 \%$ kinase activity of the group without pre-incubation (Fig 3C), indicating that hematein is a partially reversible inhibitor toward CK2.

\section{Hematein exhibits a mixed inhibition against substrate in vitro}

The Linewear-Burk plots showed that hematein exhibited a mixed inhibition against substrate RRRDDDSDDD (Fig 3D). The apparent dissociation constants for hematein binding were calculated from secondary plots of the slopes or intercepts obtained from the Linewear-Burk plots. A secondary plot of the slopes indicated a $K_{\text {is }}$ value of $0.58 \pm 0.09 \mu \mathrm{M}$ (representing a reversible binding of hematein to CK2) and a secondary plot of the y-axis inter- 
A

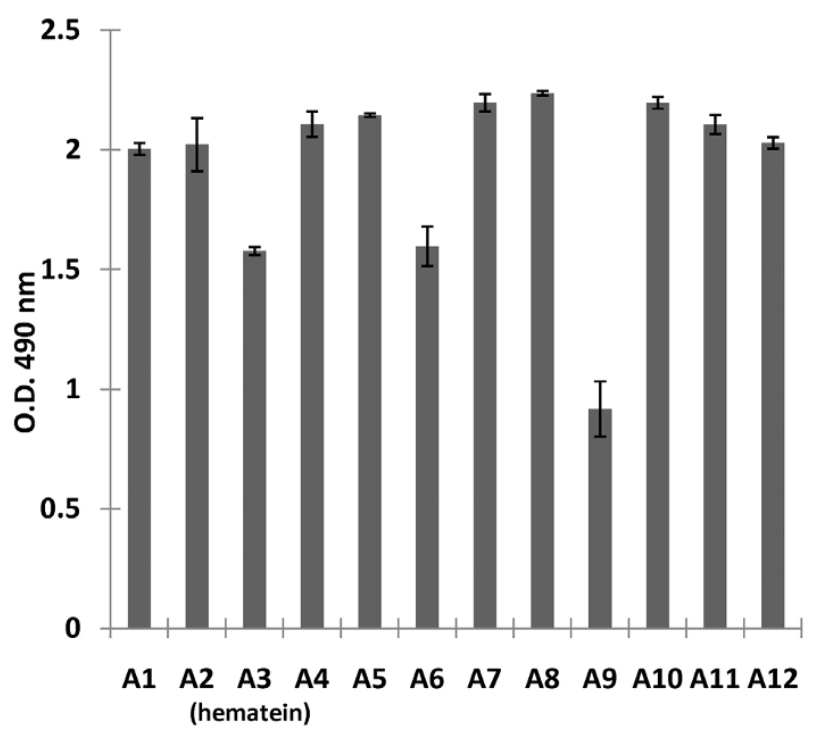

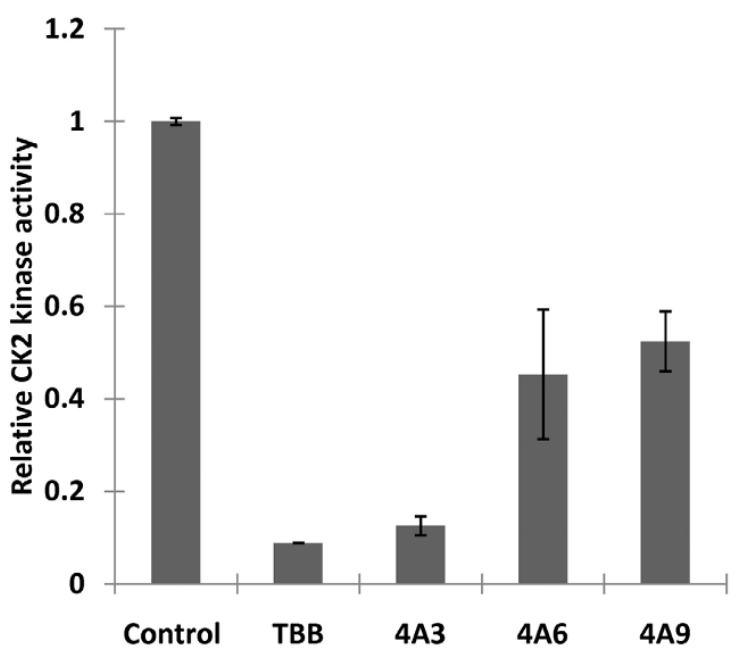

Figure I

Inhibition effects of compounds plate 4 on HCT I I 6 cells proliferation and in-vitro inhibition effects of selected compounds on CK2 kinase activity. A. After incubation with HCTI 16 cells for 48 hours, compounds 4A3 (hematein), 4A6 and 4A9 showed inhibitory effects on cell proliferation compared to the control sample (*4AI, DMSO). The longitudinal values revealed the absorbance at $490 \mathrm{~nm}$ recorded using an ELISA plate reader after addition of Cell Titer 96 AQueous One Solution Reagent to each well for 2 hours. Data represents the average of duplicate wells and bars indicate SD. Compound concentration: 4A3: I6.6 $\mu \mathrm{M}$; 4A6: 23.I $\mu \mathrm{M}$; 4A9: I4.2 $\mu \mathrm{M}$. B. Equal amounts (I00 $\mu \mathrm{M}$ ) of compounds were incubated with purified CK2, and CK2 activity was measured by Cyclex CK2 Assay/lnhibitor Screening Kit using $100 \mu M$ ATP. Ck2 kinase activity is represented as relative CK2 activity to controls (DMSO). Data represents the average of duplicate wells and bars indicate SD.4A3: hematein. Other negative results are not shown.

cepts revealed a $K_{\mathrm{ii}}$ value of $2.13 \pm 0.67 \mu \mathrm{M}$ (representing a reversible binding of hematein to CK2-substrate complex).

\section{Hematein inhibits CK2 kinase activity and down stream Akt phosphorylation, and induces apoptosis in A549 lung cancer cells}

Since CK2 kinase showed dose dependent response to hematein inhibition in vitro, we further evaluated inhibition effects of hematein on intact cancer cells. First, A549 lung cancer cells were treated with different concentrations of hematein $(0 \mu \mathrm{M}$ to $200 \mu \mathrm{M})$, and cellular viability was measured after 48 hours. Dose dependent response to inhibition of hematein was noted in A549 cells (Fig 4A). We next measured CK2 kinase activity in the lysate of these cells with the same amount of total protein via a radioisotope CK2 kinase assay described in materials and methods section. Dose dependent inhibition responses of CK2 kinase activity were noted in cells treated with $50 \mu \mathrm{M}$ and $100 \mu \mathrm{M}$ of hematein (Fig 4B). Interestingly, Akt Ser129, which is phosphorylated by CK2 in vitro and in vivo, also showed significantly decreased phosphorylation in the cells above (Fig 4C). However, total CK2, total Akt and $\beta$-actin were comparable. Increased cleaved PARP were also detected in cell lysate treated with $50 \mu \mathrm{M}$ and $100 \mu \mathrm{M}$ of hematein (Fig 4C), which indicated increased caspase dependent apoptosis of cancer cells after hematein treatment. Compared to DMSO treated cells, significantly increased apoptotic cells were noted in cells treated with $50 \mu \mathrm{M}$ and $100 \mu \mathrm{M}$ of hematein for 48 hours (Fig 4D).

\section{Hematein has more inhibition effects to cancer cells growth}

Finally, we compared inhibition effects of hematein on normal and cancer cells. Cytotoxicity of hematein against normal and cancer cells was measured using the CellTiterGlo luminescent cell viability assay (Promega, Madison, WI) to overcome the interference of hematein to MTS assay. Indicated cells were treated with different concentrations of hematein for 48 hours, and cell viability was measured by the CellTiter-Glo luminescent cell viability assay. From dose response curve, $\mathrm{IC}_{50}$ values were calculated in CCL-211 $(118.3 \pm 15.7 \mu \mathrm{M})$ and WI-38 (150.3 \pm $26 \mu \mathrm{M})$ normal cells than in Hela $(57.7 \pm 3.4 \mu \mathrm{M})$, A549 $(90.0 \pm 3.8 \mu \mathrm{M}), \mathrm{A} 427(62.9 \pm 1.7 \mu \mathrm{M})$ and HCT116 $(100.4 \pm 7.3 \mu \mathrm{M})$ cancer cells (Fig 5A). Significantly higher $\mathrm{IC}_{50}$ values $(\mathrm{p}<0.05)$ were noted in CCL-211 cells com- 
A

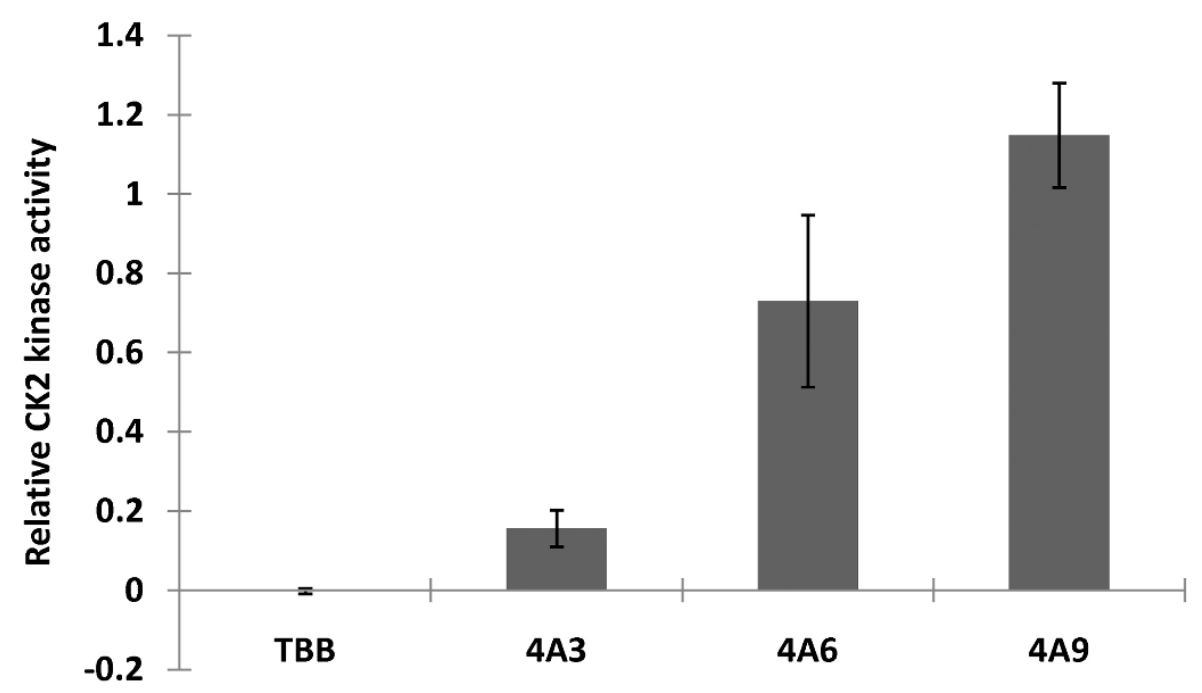

B<smiles>O=C1C=C2CC3(O)COc4c(ccc(O)c4O)C3=C2C=C1O</smiles>

4A3<smiles>COc1c2ccoc2cc2oc(=O)ccc12</smiles>

4 A6<smiles>C=C1CCC2C(C)(CO)C(O)CCC2(C)C1CC=C1C(=O)OCC1O</smiles>

4A9

Figure 2

Validation of inhibition effects of selected compounds on CK2 kinase activity and structures of compounds. A. Inhibition effects of selected compounds on CK2 kinase activity was validated by radioisotope kinase assay at a concentration of $10 \mu \mathrm{M}$ compound using $10 \mu \mathrm{M}$ ATP. TBB is the positive control. $\mathrm{Ck} 2$ kinase activity is represented as relative CK2 activity to controls (DMSO). Data represents the average of duplicate experiments and bars indicate SD.4A3: hematein. B. Structure of compounds: 4A3 (hematein): 3, 4, 10, 6a-tetrahydroxy-7, 6a-dihydroindeno [2, I-c] chroman-9-one MW 300.26, CAS No.

I5489-90-4; 4A6: 5-methoxyfurano [3,2-g]chromen-2-one; 4A9: 4-hydroxy-3-\{2- [8-hydroxy-7-(hydroxymethyl)-I,7-dimethyl3-methylenebicyclo[4. 4.0]dec-2-yl] ethylidene\}-4,5-dihydrofuran-2-one.

pared to Hela, A549 and A427 cells, and in WI-38 cells compared to Hela, A549, A427 and HCT116 cells. As the result, hematein has stronger inhibition effects towards cancer cells. We also took the advantage of the staining property of hematein to observe whether normal cells uptake hematein and hematein nuclear staining was noted in cells after treated with $50 \mu \mathrm{M}$ hematein for 48 hours (Fig 5B).

\section{Discussion}

Cell-based screening of compound libraries have been adopted to discover possible anti-cancer small molecules in myeloma, breast cancer and colon cancer cells [19-21]. In this study, we also combined a cell based assay with kinase assay for screening CK2 inhibitors from a natural compound library. Through these assays, we identified and validated hematein as a novel CK2 kinase inhibitor.

Hematein is a natural compound isolated from Caesalpinia sappan, and has been used as a herbal drug in oriental medicine as both an analgesic and an antiinflammatory agent[16] and also used in staining [22]. Our study for the first time discovered that hematein as a CK2 kinase inhibitor both in vitro and in cancer cells. The 
Table I: Specificity spectrum of hematein.

\begin{tabular}{|c|c|c|c|}
\hline Protein kinase & Kinase activity (\%) & Protein kinase & Kinase activity (\%) \\
\hline Abl & 76 & Lyn & 111 \\
\hline CDKI & 95 & MAPKI & 87 \\
\hline CDK2 & 113 & MAPK2 & 74 \\
\hline CDK3 & 55 & MKK6 & 99 \\
\hline CDK5 & 84 & MSKI & 91 \\
\hline CDK7 & 106 & MSK2 & 72 \\
\hline CHKI & 65 & mTOR & 103 \\
\hline CKI & 82 & p70S6K & 61 \\
\hline СК2 & 0 & PDGFR $\alpha$ & 103 \\
\hline cKit & 83 & PDKI & 96 \\
\hline c-RAF & 102 & Pim-I & 58 \\
\hline cSRC & 94 & Pim-2 & 81 \\
\hline DRAKI & 51 & Pim-3 & 50 \\
\hline DYRK2 & 91 & PKA & 95 \\
\hline EGFR & 31 & $\mathbf{P K B} \alpha$ & 92 \\
\hline Flt I & 31 & PKC $\alpha$ & 36 \\
\hline Flt3 & 83 & PKD2 & 58 \\
\hline GCK & 94 & PRAK & 65 \\
\hline GSK3 $\beta$ & 147 & ROCK-II & 75 \\
\hline HIPKI & 94 & SAPK2a & 121 \\
\hline HIPK2 & 76 & SAPK 3 & 99 \\
\hline HIPK3 & 96 & SAPK4 & 112 \\
\hline KDR & 62 & SGK & 92 \\
\hline Lck & 113 & Syk & 136 \\
\hline
\end{tabular}

Residual activity is determined in the presence of $10 \mu \mathrm{M}$ hematein under $10 \mu \mathrm{M}$ ATP and expressed as a percentage of the control without inhibitor. Residual activities $\leq 10 \%$ are shown in bold. CDK, cyclin-dependent kinase; CHK, checkpoint kinase; CK, casein kinase; SRC, sarcoma kinase; DRAK, DAP kinase-related apoptosis-inducing protein kinase; DYRK, dual-specificity tyrosine-(Y)-phosphorylation regulated kinase; EGFR, epidermal growth factor receptor; Flt, fms-related tyrosine kinase; GCK, gluokinase; GSK, glycogen synthase kinase; HIPK, homeodomain interacting protein kinase; KDR, kinase insert domain receptor; Lck, lymphocyte cell-specific protein-tyrosine kinase; MAPK, mitogen-activated protein kinase; MKK, mitogen-activated kinase; MSK, mitogen- and stress-activated protein kinase; mTOR, mammalian target of rapamyin; p70S6K, P70 S6 kinase; PDGFR, platelet-derived growth factor receptor; PDK, 3'-phosphoinositide-dependent kinase; PKA, protein kinase A; PKB, protein kinase B; PKC, protein kinase C; PKD, protein kinase D; PRAK, P38-regulated activated kinase; ROCK, Rho-dependent protein kinase; SRPK, serine-arginine protein kinase; SGK, serum and glucocorticoid-inducible kinase.

in vitro $\mathrm{IC}_{50}$ value of hematein $(0.55 \mu \mathrm{M})$ on $\mathrm{CK} 2$ kinase activity is comparable to other CK2 inhibitors ever discovered, such as [5-oxo-5, 6-dihydroindolo-(1, 2-a) quinazolin-7-yl] acetic acid (IQA) $(0.39 \mu \mathrm{M}), \mathrm{TBB}(0.50 \mu \mathrm{M})[1]$, $1,3,8$-trihydroxyanthraquinone (emodin) $(0.89 \mu \mathrm{M})$ and 2-Dimethylamino-4,5,6,7-tetrabromo-1 H-benzimidazole (DMAT) $(0.15 \mu \mathrm{M})[15]$. Kinetic assays in our study also showed that hematein is an ATP non-competitive inhibitor toward CK2. Non-competitive inhibitor of ATP has been shown to be less toxic, and has the advantage of no need to compete with high intracellular ATP concentration. Our data implies that hematein may inhibit CK2 through an allosteric mechanism. Recently, Raaf et al reported an allosteric binding site for the small molecule CK2 inhibitor 5,6-dichloro-1-beta-D-ribofuranosylbenzimidazole (DRB)[23]. More studies are needed to understand thoroughly the nature and mechanisms of the CK2 inhibition by hematein.

We showed that hematein also induced apoptosis of cancer cells. Earlier studies indicate that CK2 plays a key role in suppression of apoptosis. Overexpression of CK2 in cancer cells protects cells from etoposide- and diethylstilbestrol-induced apoptosis[24], results in suppression of apoptosis mediated by tumor necrotic factoralpha (TNF- $\alpha)$, TRAIL and Fas L, and augments apoptosis in cells responsive to these ligands[16]. It has been noted that treatment of a variety of cancer cells with cell permeable CK2 inhibitors such as TBB, IQA and DMAT results in activation of caspases and then aopotosis[1,14,25]. Hematein is reported to reduce the TNF- $\alpha$-induced expression of vascular cell adhesion molecule-1 (VCAM-1) and monocyte chemotactic protein-1 (MCP-1)[16,26], and to decrease reactive oxygen species generation and nuclear factor-kappa B (NF- $\kappa \mathrm{B})$ activation [27]. In our study, hematein inhibited Akt/PKB Ser129 phosphorylation in cancer cells. Akt/PKB Ser129 plays a role in constitutive activation of Akt/PKB pathway by CK2[4], which promotes cell survival through activation of anti-apoptotic pathways such as NF- $\kappa \mathrm{B}$ pathway and suppression of caspases activity[28]. Thus, hematein induces apoptosis in cancer cells at least partially through inhibition of Akt/ PKB pathway by down regulation of CK2 kinase and then decreased phosphorylation of Akt/PKB Ser129. 
A
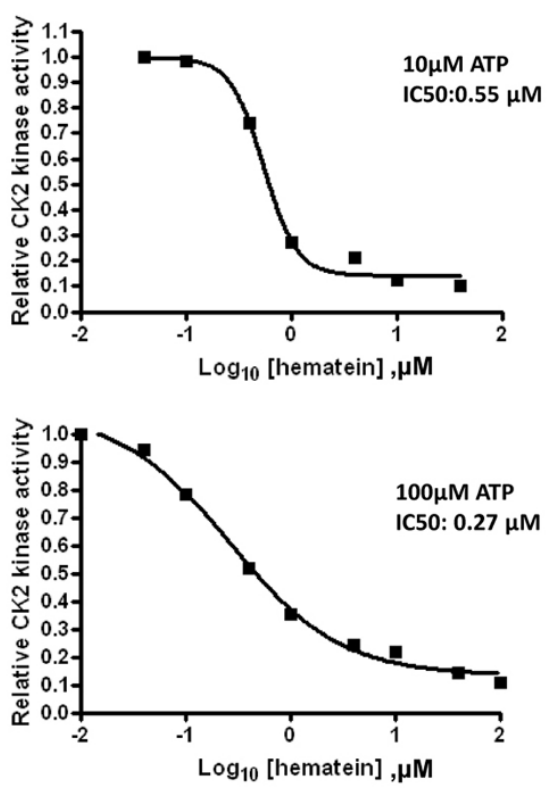

C

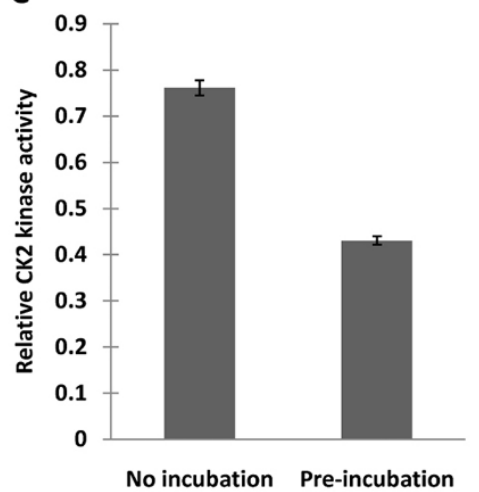

B

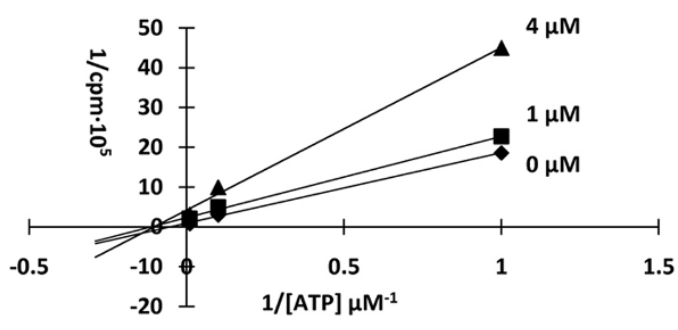

D

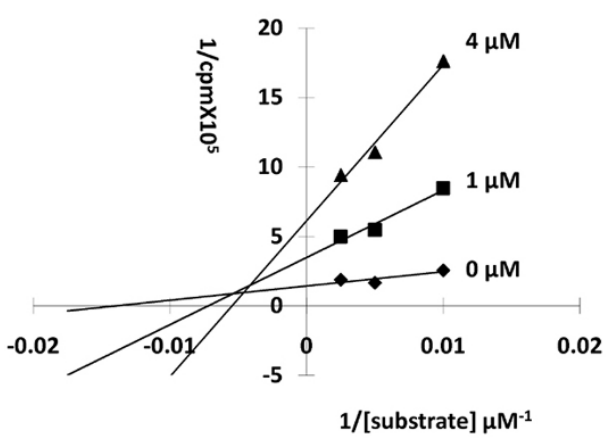

Figure 3 (see previous page)

Dose- dependent response, kinetics analysis and reversibility assay of CK2 inhibition by hematein. A. CK2 was assayed with specific peptide described in the material and method section with the increasing concentrations of the inhibitor using $10 \mu \mathrm{M}$ and $100 \mu \mathrm{M}$ ATP. B. The Linewear-Burk plots illustrate the non-competitive inhibition of hematein relative to ATP toward CK2. Substrate concentration was fixed at $200 \mu \mathrm{M}$. CK2 activity was determined in $0 \mu \mathrm{M}, \mathrm{I} \mu$ and $4 \mu \mathrm{M}$ hematein. The data represents means of duplicate experiments with SE never exceeding 10\%. C. Reversibility assay of hematein. Hematein was pre-incubated with CK2 at a concentration of $5 \mu \mathrm{M}$ for 30 minutes and then kinase assay was performed under $0.2 \mu \mathrm{M}$ final concentration of hematein. Ck2 kinase activity is represented as relative CK2 activity to controls (DMSO). Data points represent the average of duplicate experiments and bars indicate SD. D. The Linewear-Burk plots illustrate the mixed inhibition of hematein relative to substrate toward CK2. ATP concentration was fixed at $10 \mu \mathrm{M}$. CK2 activity was determined in 0 $\mu \mathrm{M}, \mathrm{I} \mu \mathrm{M}$ and $4 \mu \mathrm{M}$ hematein. The data represents means of duplicate experiments with SE never exceeding $10 \%$. 
A

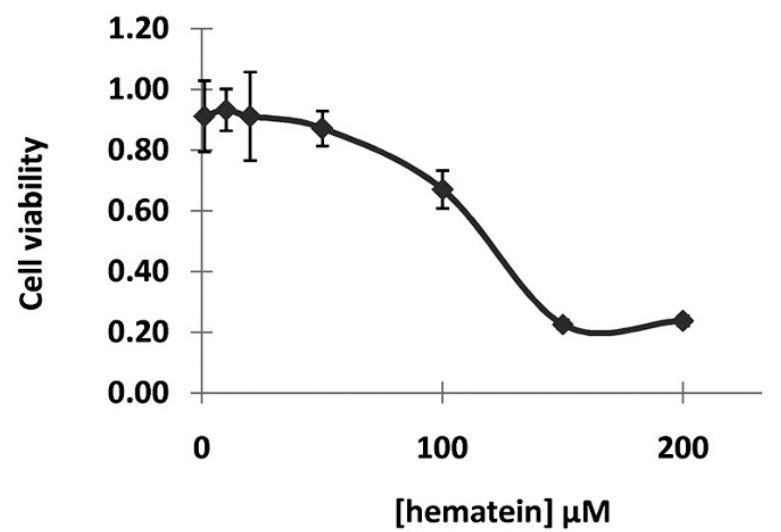

C

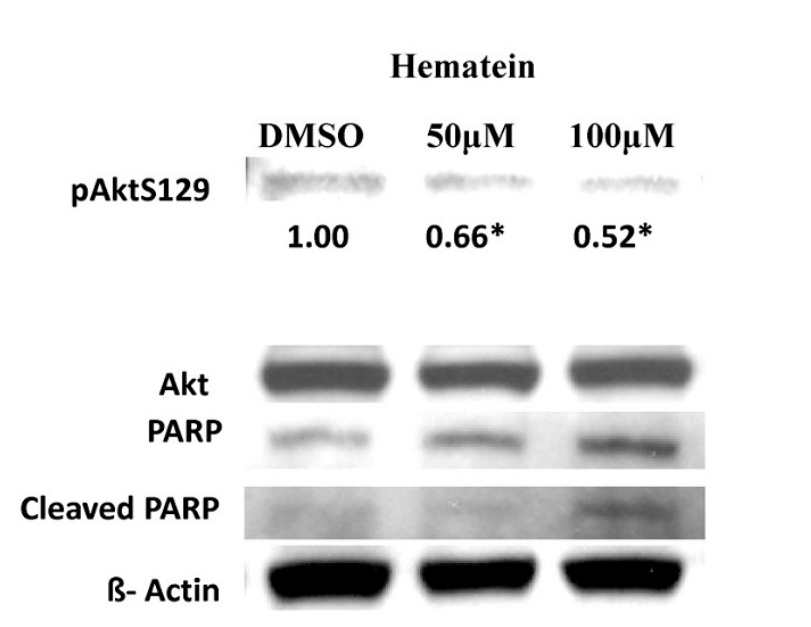

B

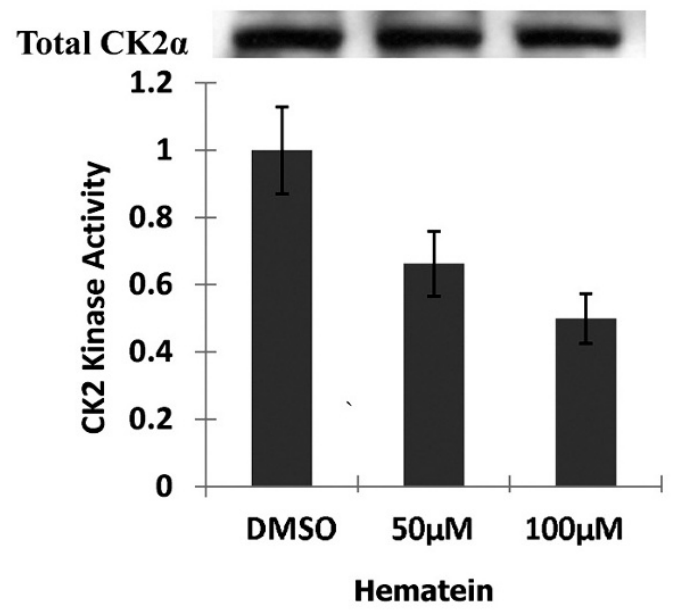

D

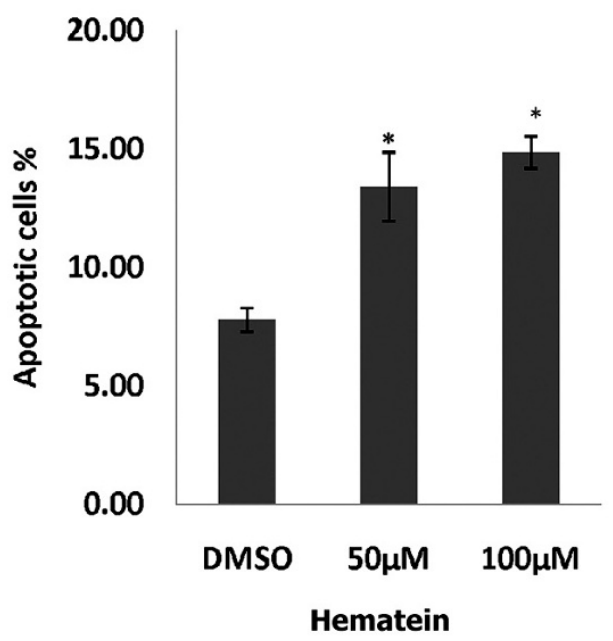

\section{Figure 4}

Inhibition effects of hematein on cellular viability and kinase activity in cancer cells. A. A549 cells were treated with serial dilutions of hematein $(0$ to $200 \mu \mathrm{M})$ and cellular viability (normalized to DMSO control) was measured after 48 hours. Data points represent the average of duplicate wells in triplet experiments and bars indicate SD. B. A549 cells were treated with DMSO (control), $50 \mu \mathrm{M}$ and $100 \mu \mathrm{M}$ of hematein for 48 hours. Upper western blot panel showed total amount of CK2 used for CK2 kinase assay, and lower table showed relative CK2 kinase activity (normalized to DMSO control) under different hematein concentrations. Data points represent the average of duplicate experiments and bars indicate SD. C. Phosphorylated Akt (Ser 129), total Akt, and PARP were measured by western blot analysis. $\beta$-Actin was used as internal loading control. Bands quantization of phosphorylated Akt (Ser 129) was obtained by an analysis with Quantity One I-D analysis software. Values are reported below each band and normalized to DMSO control. "*" denotes $p<0.05$ when compared with control values in triplet experiments. D. The fraction of cells undergoing apoptotic cell death was detected using annexin V FITC and PI stain. Data points represent the average of triplet independent experiments and bars indicate SD. "*" denotes $p<0.05$ when compared with the control values. 
A
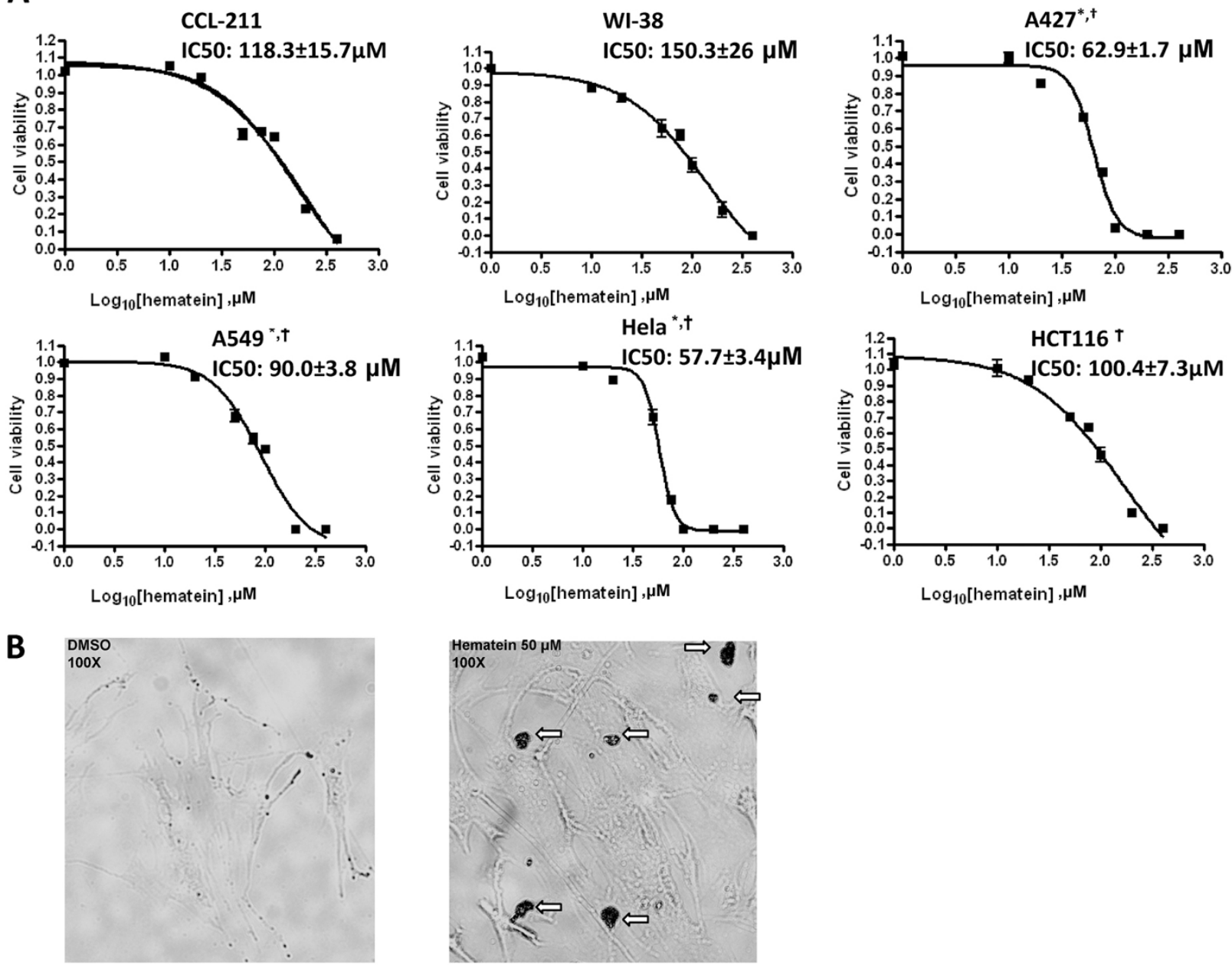

\section{Figure 5}

Inhibition effects of hematein on cellular growth in normal and cancer cells. A. Normal (WI-38, CCL-2 I I) and cancer (Hela, A549 and A427, HCTI I6) cells were cultured in the absence and in increasing concentrations of hematein (I0 $\mu$ M to $100 \mu \mathrm{M}$ ) as indicated. Cellular viability (normalized to DMSO control) was measured after 48 hours using CellTiter-Glo ${ }^{\circledR}$ Luminescent cell viability assay. Data points represent the average of $\mathrm{IC}_{50}$ value of hematein in triplet experiments and bars indicate SD. "*" denotes $p<0.05$ when compared with $I_{50}$ values of CCL-2II cells and " + " denotes $p<0.05$ when compared with $\mathrm{IC}_{50}$ values of WI-38 cells. B. CCL-2II cells were incubated in the absence and presence of $50 \mu \mathrm{M}$ hematein for 48 hours. Block arrows indicate staining of the nucleus after hematein incubation. Original magnification: $\times 100$.

Compared to TBB, hematein has similar on CK2 kinase inhibition in vitro and in cancer cells. However, TBB exerts inhibition effects on both normal and cancer cells[29]. In the contrary, hematein exerts relatively stronger inhibition effects on cancer cells than in normal cells in our study. Since hematein exerts different inhibition effects on the growth of cancer and normal cells, which is probably due to its ATP non-competitive inhibition mechanism and high selectivity. Thus, hematein may provide a clue for design of new class of CK2 inhibitors.

\section{Conclusion}

In this study, we identified hematein as a novel CK2 small molecule inhibitor from a natural compound library and showed that hematein is a selective and cell permeable CK2 inhibitor. Hematein showed stronger growth inhibition effects to cancer cells when compared to normal cells. This compound may represent a promising class of CK2 inhibitors.

\section{Competing interests}

The authors declare that they have no competing interests. 


\section{Authors' contributions}

MSH carried out the kinase assay, western blot analysis, and apoptosis studies and also drafted the manuscript. LY and DMJ designed the study and revised the manuscript. ZX, and YCL carried the kinase assay and cell lines experiments. JHM, CTY and PJC revised the manuscript. All authors read and approved the final manuscript.

\section{Acknowledgements}

We thank Naoaki Fujii, PhD, for giving us some suggestions to our study. This study was supported by NIH grant ROI CA 093708-0IA3, the Larry Hall and Zygielbaum Memorial Trust, and the Kazan, McClain, Edises, Abrams, Fernandez, Lyons and Farrise Foundation.

\section{References}

I. Sarno S, Pinna LA: Protein kinase CK2 as a druggable target. Mol Biosyst 2008, 4(9):889-894.

2. Meggio F, Pinna LA: One-thousand-and-one substrates of protein kinase CK2? Faseb J 2003, I7(3):349-368.

3. Tapia JC, Torres VA, Rodriguez DA, Leyton L, Quest AF: Casein kinase 2 (CK2) increases survivin expression via enhanced beta-catenin-T cell factor/lymphoid enhancer binding factordependent transcription. Proc Natl Acad Sci USA 2006, I 03(4 I ): I5079-|5084.

4. Di Maira G, Salvi M, Arrigoni G, Marin O, Sarno S, Brustolon F, Pinna LA, Ruzzene M: Protein kinase CK2 phosphorylates and upregulates Akt/PKB. Cell Death Differ 2005, I 2(6):668-677.

5. Tawfic S, Yu S, Wang H, Faust R, Davis A, Ahmed K: Protein kinase CK2 signal in neoplasia. Histol Histopathol 200I, 16(2):573-582.

6. Seldin DC, Leder P: Casein kinase II alpha transgene-induced murine lymphoma: relation to theileriosis in cattle. Science 1995, 267(5 | 99):894-897.

7. Landesman-Bollag E, Song DH, Romieu-Mourez R, Sussman DJ, Cardiff RD, Sonenshein GE, Seldin DC: Protein kinase CK2: signaling and tumorigenesis in the mammary gland. Mol Cell Biochem 200I, 227(I-2): I53-165.

8. Orlandini M, Semplici F, Ferruzzi R, Meggio F, Pinna LA, Oliviero S: Protein kinase CK2alpha' is induced by serum as a delayed early gene and cooperates with Ha-ras in fibroblast transformation. J Biol Chem 1998, 273(33):2129|-2/297.

9. Kim JS, Eom JI, Cheong JW, Choi AJ, Lee JK, Yang WI, Min YH: Protein kinase CK2alpha as an unfavorable prognostic marker and novel therapeutic target in acute myeloid leukemia. Clin Cancer Res 2007, 13(3): 1019-1028.

10. Laramas M, Pasquier D, Filhol O, Ringeisen F, Descotes JL, Cochet C: Nuclear localization of protein kinase CK2 catalytic subunit (CK2alpha) is associated with poor prognostic factors in human prostate cancer. Eur J Cancer 2007, 43(5):928-934.

II. P Oc, Rusch V, Talbot SG, Sarkaria I, Viale A, Socci N, Ngai I, Rao P, Singh B: Casein kinase II alpha subunit and $\mathrm{Cl}$-inhibitor are independent predictors of outcome in patients with squamous cell carcinoma of the lung. Clin Cancer Res 2004, I O(I 7):5792-5803.

12. Gapany M, Faust RA, Tawfic S, Davis A, Adams GL, Ahmed K: Association of elevated protein kinase CK2 activity with aggressive behavior of squamous cell carcinoma of the head and neck. Mol Med 1995, I (6):659-666.

13. Stalter G, Siemer S, Becht E, Ziegler M, Remberger K, Issinger OG: Asymmetric expression of protein kinase CK2 subunits in human kidney tumors. Biochem Biophys Res Commun 1994 202(I): $141-147$

14. Ruzzene M, Penzo D, Pinna LA: Protein kinase CK2 inhibitor 4,5,6,7-tetrabromobenzotriazole (TBB) induces apoptosis and caspase-dependent degradation of haematopoietic lineage cell-specific protein I (HSI) in Jurkat cells. Biochem J 2002, 364(Pt I):4I-47.

15. Pagano MA, Meggio F, Ruzzene M, Andrzejewska M, Kazimierczuk Z, Pinna LA: 2-Dimethylamino-4,5,6,7-tetrabromo-IH-benzimidazole: a novel powerful and selective inhibitor of protein kinase CK2. Biochem Biophys Res Commun 2004, 32 I (4): I040- 1044.
16. Ahmad KA, Harris NH, Johnson AD, Lindvall HC, Wang G, Ahmed $\mathrm{K}$ : Protein kinase CK2 modulates apoptosis induced by resveratrol and epigallocatechin-3-gallate in prostate cancer cells. Mol Cancer Ther 2007, 6(3): I006-I0I2.

17. Sayed M, Pelech S, Wong C, Marotta A, Salh B: Protein kinase CK2 is involved in $\mathbf{G 2}$ arrest and apoptosis following spindle damage in epithelial cells. Oncogene 200I, 20(48):6994-7005.

18. Farah M, Parhar K, Moussavi M, Eivemark S, Salh B: 5,6-Dichloroichlororibifuranosylbenzimidazole- and apigenin-induced sensitization of colon cancer cells to TNF-alpha-mediated apoptosis. Am J Physiol Gastrointest Liver Physiol 2003, 285(5):G919-928.

19. Rickardson L, Fryknas M, Haglund C, Lovborg H, Nygren P, Gustafsson MG, Isaksson A, Larsson R: Screening of an annotated compound library for drug activity in a resistant myeloma cell line. Cancer Chemother Pharmacol 2006, 58(6):749-758.

20. Evans MJ, Saghatelian A, Sorensen EJ, Cravatt BF: Target discovery in small-molecule cell-based screens by in situ proteome reactivity profiling. Nat Biotechnol 2005, 23(10): I 303-1307.

21. Teraishi F, Wu S, Zhang L, Guo W, Davis J], Dong F, Fang B: Identification of a novel synthetic thiazolidin compound capable of inducing c-Jun NH2-terminal kinase-dependent apoptosis in human colon cancer cells. Cancer Res 2005, 65(14):6380-6387.

22. Bettinger C, Zimmermann HW: New investigations on hematoxylin, hematein, and hematein-aluminium complexes. II. Hematein-aluminium complexes and hemalum staining. Histochemistry 1991, 96(3):215-228.

23. Raaf J, Brunstein E, Issinger OG, Niefind K: The CK2 alpha/CK2 beta interface of human protein kinase CK2 harbors a binding pocket for small molecules. Chem Biol 2008, I 5(2): I I I- I I7.

24. Guo C, Yu S, Davis AT, Wang H, Green JE, Ahmed K: A potential role of nuclear matrix-associated protein kinase CK2 in protection against drug-induced apoptosis in cancer cells. J Biol Chem 200I, 276(8):5992-5999.

25. Yde CW, Frogne T, Lykkesfeldt AE, Fichtner I, Issinger OG, Stenvang $\mathrm{J}$ : Induction of cell death in antiestrogen resistant human breast cancer cells by the protein kinase CK2 inhibitor DMAT. Cancer Lett 2007, 256(2):229-237.

26. Hong JJ, Jeong TS, Choi JH, Park JH, Lee KY, Seo YJ, Oh SR, Oh GT: Hematein inhibits tumor necrotic factor-alpha-induced vascular cell adhesion molecule-I and NF-kappaB-dependent gene expression in human vascular endothelial cells. Biochem Biophys Res Commun 200 I, 28 I (5): I I 27-I I 33.

27. Choi JH, Jeong TS, Kim DY, Kim YM, Na HJ, Nam KH, Lee SB, Kim HC, Oh SR, Choi YK, et al.: Hematein inhibits atherosclerosis by inhibition of reactive oxygen generation and NF-kappaBdependent inflammatory mediators in hyperlipidemic mice. J Cardiovasc Pharmacol 2003, 42(2):287-295.

28. Duncan JS, Litchfield DW: Too much of a good thing: the role of protein kinase CK2 in tumorigenesis and prospects for therapeutic inhibition of CK2. Biochim Biophys Acta 2008, I 784(I):33-47.

29. Ahmad KA, Wang G, Slaton J, Unger G, Ahmed K: Targeting CK2 for cancer therapy. Anticancer Drugs 2005, 16(10):1037-1043.

\section{Pre-publication history}

The pre-publication history for this paper can be accessed here:

\section{http://www.biomedcentral.com/1471-2407/9/135/pre} pub 